\title{
School organization and confinement. Didactic focused on reducing the impact of covid. Peiwecs
}

DOI: $10.46932 / \mathrm{sfjdv} 2 \mathrm{n} 1-028$

Received in: November 1st, 2020

Accepted in: December 30th, 2020

\author{
Andrea Luaces Galian \\ Graduada en Educación Primaria. Especialista en Audición y Lenguaje \\ Institution: RG Formación \\ Calle Rosalía de Castro, 44, 30107 Murcia \\ Ángela García Nicolás \\ Graduada en Educación Primaria. Especialista en Audición y Lenguaje \\ Institution: RG Formación \\ Calle Rosalía de Castro, 44, 30107 Murcia \\ Jose María Rabal Alonso \\ Professor ISEN Centro Universitario \\ Institution: Universidad de Murcia \\ Calle Campus Universitario, 12, 30100 Murcia \\ E-mail: josemaria.rabal@um.es
}

\begin{abstract}
Emotions are present in our lives since we are born and play an important role in the construction of our personality and social interaction. School is another area of knowledge and experiences in which emotions develop since education contemplates the integral development of people. This can start from Early Childhood Education. For this, the figure of the teacher is relevant, since it is the one that provides the monitoring programs, becoming a model for the students, with which they can acquire the development of interpersonal and intrapersonal intelligence that will make them adapt to society and they will acquire a personal motivation towards any element that we propose. This will lead to proper affective growth in which you must learn to manage both positive and negative emotions. But for this, the teacher must individualize the teaching to each of his students, since each student in the personal sphere has experienced different situations with different contexts. Thus, pedagogical action aims to promote the acquisition of emotional skills through strategies and experiences such as stories, puppets, some dramatizations and the use of resources from everyday life.
\end{abstract}

KEYWORDS: emotions, Early Childhood Education, interpersonal and intrapersonal intelligence, affective growth, pedagogical performance.

\section{THEORETICAL FRAMEWORK}

Emotional intelligence must be developed in people's lives, since Emotions are present in our lives since we are born and play a relevant role in the construction of our personality and social interaction (López, 2005, p.153) . We experience emotions in any space and time. So school is another area of knowledge and experiences in which emotions develop (López, 2005, p.153). This has the purpose of 
educating, what we can define as "contemplating the integral development of people, developing cognitive, physical, linguistic, moral, affective and emotional capacities" (López, 2005, p.153). Emotional education adopts a life cycle approach that is put into practice through sequenced programs, that can begin in early childhood education, since it is vitally important to guide all the educational work of the boys and girls to their integral development (López, 2005). In addition, those that are related to emotional competences must be valued as necessary, since they establish tools for progress and psychological growth (Gutiérrez, Escartí and Pascual, 2011) where the maintenance of a correct emotional well-being is implied in which positive emotions promote Determined cognitive abilities thus increasing intellectual means, academic performance and the resolution of complex situations. Including, the establishment of social relationships. Which makes education imply, since it is in the context in which cognitive intelligence and success in different areas of life develop. since, it is of vital importance to guide all the educational work of the boys and girls to the integral development of these (López, 2005). In addition, those that are related to emotional competences must be valued as necessary, since they establish tools for progress and psychological growth (Gutiérrez, Escartí and Pascual, 2011) where the maintenance of a correct emotional well-being is implied in which positive emotions promote Determined cognitive abilities thus increasing intellectual means, academic performance and the resolution of complex situations. Including, the establishment of social relationships. Which makes education imply, since it is in the context in which cognitive intelligence and success in different areas of life develop. since, it is of vital importance to guide all the educational work of the boys and girls to the integral development of these (López, 2005). In addition, those that are related to emotional competences must be valued as necessary, since they establish tools for progress and psychological growth (Gutiérrez, Escartí and Pascual, 2011) where the maintenance of a correct emotional well-being is implied in which positive emotions promote Determined cognitive abilities thus increasing intellectual means, academic performance and the resolution of complex situations. Including, the establishment of social relationships. Which implies Education, since it is in the context in which cognitive intelligence and success in different areas of life develop. It is vitally important to guide all the educational work of the boys and girls to their integral development (López, 2005). In addition, those that are related to emotional competences must be valued as necessary, since they establish tools for progress and psychological growth (Gutiérrez, Escartí and Pascual, 2011) where the maintenance of a correct emotional well-being is implied in which positive emotions promote Determined cognitive abilities thus increasing intellectual means, academic performance and the resolution of complex situations. Including, the establishment of social relationships. Which makes education imply, since it is in the context in which cognitive intelligence and success in different areas of life develop. It is vitally important to guide all the educational work of the boys and girls to their integral development (López, 
2005). In addition, to value them as necessary those that are related to emotional competences, since they establish tools for progress and psychological growth (Gutiérrez, Escartí and Pascual, 2011) where the maintenance of a correct emotional well-being is implied in which positive emotions promote Determined cognitive abilities thus increasing intellectual means, academic performance and the resolution of complex situations. Including, the establishment of social relationships. Which makes education imply, since it is in the context in which cognitive intelligence and success in different areas of life develop. 2005). In addition, those that are related to emotional competences must be valued as necessary, since they establish tools for progress and psychological growth (Gutiérrez, Escartí and Pascual, 2011) where the maintenance of a correct emotional well-being is implied in which positive emotions promote Determined cognitive abilities thus increasing intellectual means, academic performance and the resolution of complex situations. Including, the establishment of social relationships. Which implies Education, since it is in the context in which cognitive intelligence and success in different areas of life develop. 2005). In addition, those that are related to emotional competences must be valued as necessary, since they establish tools for progress and psychological growth (Gutiérrez, Escartí and Pascual, 2011) where the maintenance of a correct emotional well-being is implied in which positive emotions promote Determined cognitive abilities thus increasing intellectual means, academic performance and the resolution of complex situations. Including, the establishment of social relationships. Which makes education imply, since it is in the context in which cognitive intelligence and success in different areas of life develop. since they establish tools of progress and psychological growth (Gutiérrez, Escartí and Pascual, 2011) where the maintenance of a correct emotional well-being is implied in which positive emotions promote determined cognitive abilities thus increasing intellectual means, academic performance and the resolution of situations complex. Including, the establishment of social relationships. Which makes education imply, since it is in the context in which cognitive intelligence and success in different areas of life develop. since they establish tools of progress and psychological growth (Gutiérrez, Escartí and Pascual, 2011) where the maintenance of a correct emotional well-being is implied in which positive emotions promote certain cognitive abilities thus increasing intellectual means, academic performance and the resolution of situations complex. Including, the establishment of social relationships. Which makes education imply, since it is in the context in which cognitive intelligence and success in different areas of life develop. Including, the establishment of social relationships. Which makes education imply, since it is in the context in which cognitive intelligence and success in different areas of life develop. Including, the establishment of social relationships. Which makes education imply, since it is in the context in which cognitive intelligence and success in different areas of life develop. 
"The role of the educator, and especially in early childhood education, is that of mediator of learning" (López, 2005, p. 163). In this way, it offers a model of action that children imitate and internalize in their habitual behaviors. In addition, the teacher must transmit and offer security and confidence to the students, creating contexts of communication and affection where they feel comfortable and can develop according to their personality and characteristics. Well, emotional security is a basic element for the boy or girl to dare to discover their environment and obtain different experiences, being the teacher together with the collaboration of families who promote the concept of themselves. (López, 2005).

With this, it is observed that the work of the teacher is not limited to the teaching of contents that are addressed in a curriculum, but the integral development of the student, including the recognition and importance of emotional education for boys and girls. Moreover, emotions are involved in the development of the cognitive field, since students must be able to recognize and control their own emotions, as well as motivate themselves and understand the emotions of others, as described from the theory of multiple intelligences of Gardner (1995), where multiple intelligences are distinguished (Gardner, 2001) among which interpersonal intelligence stands out (Interpersonal intelligence is built from the ability to establish distinctions between people, awaken the feeling of empathy,

This world of feelings will make us adapt better in society, as well as in personal motivation towards any elements that we propose, since these feelings push us to make certain decisions or carry out actions. Which leads us to the development of a correct affective growth with which it is necessary that both negative emotions (sadness, anger and fear) and positive emotions (joy, interest, satisfaction and session and love), as well as others such as empathy, guilt and shame, combine and complement each other (Fredrickson, 2001) to have a good evolutionary development (Vecina, 2006).

However, each student is different and not all start from the same level of emotional intelligence, since this is worked both in the classroom and at home, using these different parenting modes focused on their emotions, which makes teaching difficult. Despite this, emotional education is an educational innovation that aims to develop emotional skills that contribute to better personal and social well-being (Bisquerra, 2003). For this reason, the teacher must have as an essential objective to know what an emotion is and what implications for practice are derived from this concept.

The concept tells us that an emotion is produced thanks to sensory information reaching the emotional centers of the brain, as a consequence there is a neurophysiological response, and the neocortex interprets the information. Therefore it can be considered that "an emotion is a complex state of the organism characterized by an excitement or disturbance that predisposes to an organized response. Emotions are generated in response to an external or internal event ". (Bisquerra, 2003, p.12). 
In this way it can be said that there are three components in an emotion, neurophysiological, behavioral and cognitive. The neurophysiological is manifested in responses such as tachycardia, sweating, hypertension, muscle tone, redness, dry mouth, changes in neurotransmitters, hormonal secretions, respiration, etc. All of these are involuntary responses, which the subject cannot control. However, they can be prevented by appropriate techniques such as relaxation, which the teacher should be aware of, since, as a consequence of intense and frequent emotions, health problems (tachycardia, hypertension, ulcer, etc.) can occur. For this reason, the prevention of the harmful effects of emotions in the framework of emotional education can be understood as an aspect of health education. (Bisquerra, 2003).

It is convenient that emotional intelligence is developed and improved individually by making them aware of their emotions, that of others and their causes, since there is a balance between the rational and the emotional. Which helps to overcome the maladjustments that we sometimes find by enhancing intelligence, since emotions facilitate learning both academically and to lead a full life (FernándezMartínez, \& Montero-García, 2016).

Teachers must maintain an example, since students learn by imitation, so they in turn better engage, understand and understand students Kremenitzer and Miller (2008). In the same way, they learn when educators program their transversal and attitudinal contents, since a program is developed whose purpose is to develop emotional skills in children so that they learn to regulate their emotions using methods aimed at emotional plasticity, since the recognition of emotions seems to be a central aspect in the social adaptation of people in many age ranges (Tarnowski, Kołodziej, Majkowski, \& Rak, 2017).

For all these reasons, educating emotionally means promoting the integral development of children, providing strategies for the development of emotional competencies for balance and the enhancement of self-esteem, attitudes of respect, tolerance and prosociality, as well as the capacity for effort and motivation towards work, development of tolerance to frustration, the ability to relate to oneself and with others in a satisfactory way, control of impulsivity, promote self-knowledge and knowledge of others and the quantity and quality of group interactions to improve the relational climate of class and group cohesion.

With all this, it is intended that they acquire an emotional awareness knowing their own emotional state and expressing it through verbal and / or non-verbal language, as well as recognizing the feelings and emotions of others; that they know how to regulate and tolerate unpleasant impulses and emotions; and have self-esteem. (Fernández-Martínez and Montero-García, 2014).

The pedagogical performance aims to promote the acquisition of emotional competencies through emotional and experiential strategies such as stories, puppets and some dramatizations; as well as in the 
use of resources from everyday life: press news, family photographs, songs, skirt games, etc. (López, 2005).

This requires the development and elaboration of certain tasks or activities that can be carried out in the classroom. Among the possible activities for improvement are the development of the ability to identify, express and recognize one's own emotions, thanks to the aspects that stand out in these, such as facial expression (eyes and mouth) that is reflected at first sight of the emotions. people and the configuration (look and position of the corner of the lips), with which various areas of the brain are involved; the gaze, which is related to the intraparietal sulcus (Hoffman and Haxby, 2000) and the amygdala, which is responsible for processing the content of emotions (Saavedra, Díaz, Zúñiga, Navia and Zamora, 2015). For this, the activity could be the expression of emotions with different images and a situation in which they were in that way must be described. Another activity when drawing a card with an expression should change the children's face as it is expressed on the card (López, 2005).

Among the different tasks that could be developed, it could be learning to transform negative emotions into positive ones, for this, through incomplete stories, they can be asked about the way they will act. (Grimaldo, 2020).

They also "must be able to know, value and accept their capacities and limitations without ceasing to love themselves" (Fernández-Martínez and Montero-García, 2014, p.62), so they must recognize their qualities, Through the stories, they should think if they had performed the same action as the protagonist or a different one.

For the development of socio-emotional skills, various investigations have been developed whose purpose is to increase the socialization of emotions both in preschool boys and girls and in their respective parents, using different parenting approaches focused on their emotions with the pretext of exercising their emotional abilities, so that boys and girls simultaneously improve their relationships and consequently their behavior. An example that could be developed is through films in which scenes are presented and they must say if the way of acting is appropriate and what they do in their case (FernándezMartínez and Montero-García, 2014).

As a conclusion, the need to execute programs aimed at the development and improvement of the emotional world is evident, since its importance should be considered as one more content to educate to favor the integral development of people (Colasante, et al. 2015; López, 2005) . Intervening at an early age enables the development of healthy behaviors in the future (Garaigordobil, 2003). 


\section{INSTRUMENT:}

"The questionnaire is an instrument used to collect information designed to quantify and universalize the information and standardize the interview process. Its purpose is to achieve the comparability of the information in a systematic and orderly manner, about the population with which one works, about the variables that are the object of the investigation or evaluation "(Martín, 2004, p. 23).

"The evaluation scales are those instruments / questionnaires that allow a cumulative scaling of their items giving global scores" (Martín, 2004, p. 23).

Among the different types of scales, the Likert-type scales will be selected for the present work, which are psychometric instruments where the respondent must indicate their agreement or disagreement about a statement, item or reagent, which is done through an ordered and one-dimensional scale. These instruments are usually recognized among the most used for measurement in Social Sciences and Education Sciences, arising when Rensis Likert published a report in which he exposed how to use a type of instrument to measure attitudes (Matas, 2018).

For the application of a Likert scale, one must take into account what is to be measured, the formulation and analysis of the propositions used to eliminate inappropriate ones, application of the questionnaire with scalar questions to a sample population, calculation of scalar scores. individual and tabulate the responses (Aigneren, 2010).

These scales originally consisted of a collection of items, half expressing a position in accordance with the attitude to be measured and the other half against. Each item was accompanied by an ordinal rating scale. This scale included a neutral midpoint, as well as points to the left and right, originally of disagreement and agreement, with numerical response options from 1 to 5. However, there are other ways to collect information, although each has direct implications. in the measurement process and, therefore, in the quality of the data, as well as in the interpretability of the results. Well, if the intermediate alternative is eliminated, leaving four options forces the respondent to position himself for or against the item. For this reason, an intermediate category is included, since it is advisable not to force this choice to avoid inducing an error in the data. Although, this also has consequences since they can select the intermediate one to present indifference, ambivalence, lack of understanding or suspicion for revealing personal issues (Fabila, Minami \& Izquierdo, 2012).

Among the types of respondents that we can find, we find the ambivalent, which is the group of respondents who choose the intermediate option because they really position themselves between the two extremes; the indifferent are those who have no interest in the subject or are not involved in answering competently; the acquiescent, those who try to answer what they think others expect them to answer; and those who avoid or hide socially undesirable opinions, since they avoid choosing options that are frowned 
upon among their peer or reference group (Matas, 2018). In this way, we see that there are different types of people who choose this option due to various factors, such as having no opinion or undecided. For this reason, an extra box is sometimes created in which they can not comment,

In this way, Likert scales are an entertaining and simple way, where the different relative data for the investigation are collected, but the way of use of these must be taken into account, since it will vary depending on what we hope to study through the questionnaire (Fabila, Minami and Izquierdo, 2012).

\section{CREATION, CONFORMATION AND VALIDATION PROCESS}

To obtain a reliable source of information and allow sufficient samples to summarize the results, it is essential that the tools used to collect it are sufficient. In this sense, following authors such as Alonso, Bernal, Martínez, Escolar \& Romero, M., (2020) and Alonso, Flores, Murcia, \& Romero, (2020), the most useful tools are undoubtedly the questionnaires that are easy to copy and use. The tool itself gets the most benefit from the data results.

As mentioned above, it is not just a proposal, but a questionnaire with detailed theoretical support and subsequent verification by experts. The confirmation process of the attached questionnaire includes sharing with professionals active in early childhood education, primary and secondary education, and university education; Due to its wide range, the results can be inferred for people of any age. Everyone was asked to write down the time the questionnaire was completed to confirm that the filling was completed in a short period of time. The result is that completing these tasks is short-lived, passing them on to large numbers of volunteers is not an obstacle, and because it is easy to complete, the possible crowd is large.

The aforementioned questionnaire consists of a series of parts (one for each research variable), which must be completed by the respondent.

The process object of elaboration of this questionnaire studied in depth, it was conceived in two stages. The first stage is a detailed bibliographic analysis of variables related to emotional intelligence. The annex introduces that the second basic pillar that covers the validity and importance of this questionnaire is the indispensable participation of different experts in the field. These experts include experts in university teaching, primary and secondary education, therapy and early childhood education, all of them directly related to the field of research.

As a standard for the conservation of objects, a method similar to that described in previous studies carried out by Alonso, Bernal, Martínez, Escolar \& Romero, M., (2020) and Alonso, Flores, Murcia, \& Romero, (2020) includes at least 3/4 of the experts (at least 5 points) Three points or less were reviewed 
or discarded between two or more evaluators. Since the elements of the questionnaire are selected in detail, they do not need to be discarded or modified.

Due to their applicability and ease of use, all these results have resulted in a questionnaire adequate enough to advocate for high-quality teaching and to look for areas of future research that can be improved or improved.

\section{LIMITATIONS}

Likewise, we believe that a final identification is necessary in order to collect and specify the problems that occurred during the preparation of this study or the study. In this way, we can specify the restrictions that are proposed to us throughout the research process, which will help future research related to this topic.

In this sense, as a first restriction, we must refer to the immediate environment or special circumstances in which we currently find ourselves. Due to this health crisis, we are limited in finding basic documents and publications that can provide the basis and foundation for this research. Due to mobility restrictions, we cannot delve into certain specialized institutions in this matter.

Therefore, to properly conduct this research, we must rely on electronic resources. Therefore, we cannot extend the information to the level we want.

On the other hand, considering another limitation, because we have not received subsidies, we have not received specific and specific help regarding the benefits of resources, materials and means to deepen the search for information. In this way, we rely on our knowledge of databases and scientific resources to be able to adapt to the correct method of this research.

\section{CONCLUSIONS}

Emotions accompany us during each of the experiential moments in our life. Which makes it necessary for each person individually to know how to control the different emotions, for this, he must know what he feels on each occasion, as well as what the other person feels when the emotion involves a social act. In this way, as education is in charge of the integral development of the student, this type of content must be worked on, so that the student knows how to cope with the environment. This implies the training of teachers in this area and collaboration with other agents involved in the learning process such as families. In this way, it is necessary to know how emotion is produced and the different methodologies and activities that can be developed to work on these, such as role playing, symbolic play, etc. In turn, the level of the student must be taken into account and their learning process individualized to their characteristics, so that everyone can achieve the final objective. 


\section{REFERENCES}

Alonso, J. M. R., Bernal, C. B., Martínez, J. M. G., Escolar, P. M., \& Romero, M. G. (2020). Importancia De La Práctica Deportiva En Edad Escolar: Validación Cuestinoario Cudaeem./Importância Da Prática Esportiva Na Idade Escolar: Validação Do Questionário De Cudaeem. Brazilian Journal of Development, 6(4), 21598-21615.

Alonso, J. M. R., Flores, C. M. C., Murcia, C. C., \& Romero, M. G. (2020). Importancia del tratamiento de la muerte en el ámbito educativo: validación cuestionario ciem/Importância do tratamento da morte no contexto educacional: validação do questionário ciem. Brazilian Journal of Development, 6(4), 1835518365.

Aigneren, M. (2010). Técnicas de medición por medio de escalas. La Sociología En Sus Escenarios, (18). En https://revistas.udea.edu.co/index.php/ceo/article/view/6552

Bisquerra, R. (2003). Educación Emocional y competencias básicas para la vida. Revista de Investigación Educativa, 21 (1), pp. 7-43

Colasante, T., Zuffianò, A., y Malti, T. (2015). Do moral emotions buffer the anger-aggression link in children and adolescents? Journal of Applied Developmental Psychology, 41, pp. 1-7.

Fabila, A.M., Minami, H., Izquierdo M.J. (2012). La Escala de Likert en la evaluación docente: acercamiento a sus características y principios metodológicos. Perspectivas docentes, (50), pp. 31-40.

Fernández-Martínez, A. M. y Montero-García, I. (2016). Aportes para la educación de la Inteligencia Emocional desde la Educación Infantil. Revista Latinoamericana de Ciencias Sociales, Niñez y Juventud, 14 (1), pp. 53-66. En https://www.redalyc.org/articulo.oa?id=77344439002

Fredrickson, B. L. (2001). The role of positive emotion in positive psychology: The broaden and build theory of positive emotion. American Psychologist, 56, pp. 218-226.

Garaigordobil, M. (2003). Intervención psicológica para desarrollar la personalidad infantil: Juego, conducta prosocial y creatividad. Madrid: Pirámide.

Gardner, H. (1995). Inteligencias Múltiples. La Teoría en la Práctica. Barcelona: Paidós.

Gardner, H. (2001). La inteligencia reformulada : las inteligencias múltiples en el siglo XXI. Barcelona: Paidós.

Grimaldo Muchotrigo, M., \& Merino-Soto, C. (2020). Efectos de un Programa de Intervención sobre las habilidades emocionales en niños preescolares. REOP - Revista Española de Orientación y Psicopedagogía, 31(1), 62. https://doi.org/10.5944/reop.vol.31.num.1.2020.27290

Gutiérrez, M., Escartí. A., y Pascual, C. (2011). Relaciones entre empatía, conducta prosocial, agresividad, autoeficacia y responsabilidad personal y social de los escolares. Psicothema 23(1), pp.13-19.

Hoffman, E. A., y Haxby, J. V. (2000). Distinct representations of eye gaze and identity in the distributed human neural system for face perception. Nature neuroscience, 3(1), 80-84 
Kremenitzer, J. P. y Miller, R. (2008). Are You a Highly Qualified, Emocionally Intelligent Early Childhood Educator? Young Children, 63 (4), pp. 106-112.

López, E. (2005). La educación emocional en la educación infantil. Revista Interuniversitaria de Formación del Profesorado , 19 (3), 153-167. En https://www.redalyc.org/pdf/274/27411927009.pdf

Martín M.C. (2004). Diseño y validación de cuestionarios. Matronas Profesión, 5 (17). En http://ebevidencia.com/wp-content/uploads/2014/07/validacion_cuestionarios.pdf

Matas, A. (2018). Diseño del formato de escalas tipo Likert: un estado de la cuestión. Revista Electrónica de Investigación Educativa, 20 (1), 38-47. https://doi.org/10.24320/redie.2018.20.1.1347

Saavedra, J.S., Díaz, W.J., Zúñiga, L.F. y Zamora, T.O. (2015). Correlación funcional del sistema límbico con la emoción, el aprendizaje y la memoria. Morfolia, 7(2), pp. 29-44.

Tarnowski, P., Kołodziej, M., Majkowski, A., y Rak, R. J. (2017). Emotion recognition using facial expressions. Procedia Computer Science, 108, pp. 1175-1184.

Vecina, M.L. (2006). Emociones Positivas. Papeles del Psicólogo, 27(1). pp. 9-17 
Questionnaire Perception Importance of working on emotions to prevent states derived from confinement and stress COVID (PEIWECS)

Presentation: this questionnaire presents a series of items related to the perception of emotional competence and its importance in education.

Instructions: to correctly complete the questionnaire, you must read, understand and reflect on each statement or item, indicating — by means of an " $\mathrm{X}$ " in the corresponding box-, among the different grades (from 1 to 5), the one that you consider most appropriate to your thought.

We would like to have your cooperation. The questionnaire is ANONYMOUS, so please answer the questions posed as honestly as possible - there are no right or wrong answers. The duration of completion of this questionnaire will be less than 5 minutes.

\begin{tabular}{|c|c|c|c|c|c|}
\hline ITEMS & 1 & 2 & 3 & 4 & 5 \\
\hline 1. The participatory methodology helps to teach to recognize positive emotions. & & & & & \\
\hline $\begin{array}{l}\text { 2. The participatory methodology helps to teach to recognize negative } \\
\text { emotions. }\end{array}$ & & & & & \\
\hline 3. The participatory methodology helps to teach to recognize joy. & & & & & \\
\hline 4. Participatory methodology helps teach to recognize interest & & & & & \\
\hline 5. The participatory methodology helps to teach to recognize satisfaction & & & & & \\
\hline 6. The participatory methodology helps to teach to recognize love & & & & & \\
\hline 7. The participatory methodology helps to teach to recognize sadness & & & & & \\
\hline 8. The participatory methodology helps teach to recognize anger & & & & & \\
\hline 9. The participatory methodology helps to teach to recognize fear & & & & & \\
\hline $\begin{array}{l}\text { 10. For the recognition of negative emotions, participatory methodologies do not } \\
\text { help in this }\end{array}$ & & & & & \\
\hline $\begin{array}{l}\text { 11. Participatory methodologies do not cooperate for the distinction of emotions } \\
\text { such as anger }\end{array}$ & & & & & \\
\hline $\begin{array}{l}\text { 12. The moral emotion of satisfaction cannot be recognized through a } \\
\text { participatory pedagogy }\end{array}$ & & & & & \\
\hline $\begin{array}{l}\text { 13. To recognize positive emotions, a participatory and collaborative } \\
\text { methodology is not required }\end{array}$ & & & & & \\
\hline
\end{tabular}

